\title{
Incisor root length in individuals with and without anterior open bite: a comparative CBCT study
}

\author{
Luis Ernesto Arriola-Guillénn ${ }^{1,2}$, Ivy Samantha Valera-Montoya ${ }^{1}$, Yalil Augusto Rodríguez-Cárdenas ${ }^{3}$. \\ Gustavo Armando Ruíz-Mora ${ }^{4}$, Aron Aliaga-Del Castillo5, Guilherme Janson ${ }^{5}$
}

DOI: https://doi.org/10.1590/2177-6709.25.4.23.e1-7.err

Objective: This study aimed to compare the root length of maxillary and mandibular incisors between individuals with open bite versus matched individuals with adequate overbite. Methods: This comparative, matched and retrospective study included 48 cone beam computed tomographies (CBCTs) obtained at a university radiological center. Scans belonged to 24 individuals with open bite (overbite $\leq 0 \mathrm{~mm}$ ) and 24 individuals with adequate overbite (controls). Both groups were matched by age, sex, malocclusion classification and skeletal characteristics (ANB and FMA angles). Root length of each maxillary and mandibular incisor was measured in millimeters ( $\mathrm{mm}$ ) in a sagittal section from a perpendicular line to the enamel cement junction until the root apex (384 length measurements were made). The means of root length in both groups were compared using $t$-tests. In addition, correlations between variables were evaluated with the Pearson correlation coefficient $(\alpha=0.05)$. Results: In both groups, the root length of the upper central incisors was approximately $12 \mathrm{~mm}$ and the root length of the maxillary lateral incisors was approximately $13 \mathrm{~mm}(p>0.05)$. Likewise, the root length of lower central incisors in both groups measured approximately $12 \mathrm{~mm}(p>0.05)$. However, the mandibular lateral incisor roots of open bite patients were significantly longer than in the normal overbite patients (approximately $1 \mathrm{~mm}, p=0.012$ right side, $p=0.001$ left side). Conclusions: Root length of maxillary incisors and central mandibular incisor is similar in individuals with or without open bite, but the mandibular lateral incisor roots in open bite patients were significantly longer than in the normal overbite patients.

Keywords: Open bite. Incisor. Root length. Cone-beam computed tomography.

Objetivo: O presente estudo teve como objetivo comparar o comprimento radicular de incisivos superiores e inferiores em indivíduos com mordida aberta versus indivíduos com sobremordida normal. Método: Esse estudo comparativo e retrospectivo incluiu 48 tomografias computadorizadas de feixe cônico (TCFC) obtidas em um centro radiológico universitário. As tomografias foram realizadas em 24 indivíduos com mordida aberta (sobremordida $\leq 0 \mathrm{~mm}$ ) e 24 indivíduos com sobremordida normal (controle). Ambos os grupos foram compatibilizados de acordo com a idade, sexo, má oclusão e padrão esquelético (ângulos ANB e FMA). O comprimento radicular de todos os incisivos superiores e inferiores foi medido em milímetros $(\mathrm{mm})$ em um corte sagital, de uma linha perpendicular à junção cemento-esmalte até o ápice radicular (384 medidas de comprimento foram realizadas). A média de comprimento radicular em ambos os grupos foi comparada utilizando-se o teste $t$. Adicionalmente, correlações entre as variáveis foram avaliadas usando o coeficiente de correlação de Pearson $(\alpha=0,05)$. Resultados: Em ambos os grupos, o comprimento radicular dos incisivos centrais superiores foi de, aproximadamente, $12 \mathrm{~mm}$, e o comprimento radicular dos incisivos laterais superiores foi de, aproximadamente, $13 \mathrm{~mm}(p>0,05)$. Da mesma forma, o comprimento radicular dos incisivos centrais inferiores, em ambos os grupos, obteve a medida de aproximadamente $12 \mathrm{~mm}(p>0,05)$. No entanto, o comprimento radicular dos incisivos laterais inferiores em indivíduos com mordida aberta foi significativamente maior em comparação aos pacientes com sobremordida normal (aproximadamente $1 \mathrm{~mm}, p=0,012$ do lado direito, $p=0,001$ do lado esquerdo). Conclusões: $\mathrm{O}$ comprimento radicular de incisivos superiores e incisivos centrais inferiores foi similar em indivíduos com ou sem mordida aberta, mas o comprimento radicular de incisivos laterais inferiores em indivíduos com mordida aberta foi significativamente maior em comparação a pacientes com sobremordida normal.

Palavras-chave: Mordida aberta. Incisivo. Comprimento radicular. TCFC.

${ }^{1}$ Universidad Científica del Sur, School of Dentistry, Division of Orthodontics (Lima, Peru).

${ }^{2}$ Universidad Científica del Sur, School of Dentistry, Division of Oral and Maxillofacial Radiology (Lima, Peru).

${ }^{3}$ Universidad Nacional de Colombia, Faculty of Dentistry, Division of Oral and Maxillofacial Radiology (Bogotá, Colombia).

${ }^{4}$ Universidad Nacional de Colombia, Faculty of Dentistry, Division of Orthodontics (Bogotá, Colombia).

${ }^{5}$ Universidade de São Paulo, Faculdade de Odontologia de Bauru, Departamento de Ortodontia (Bauru/SP, Brazil).
How to cite: Arriola-Guillén LE, Valera-Montoya IS, Rodríguez-Cárdenas YA, Ruíz-Mora GA, Aliaga-Del Castillo A, Janson G. Incisor root length in individuals with and without anterior open bite: a comparative CBCT study. Dental Press J Orthod. 2020 Jul-Aug;25(4):23e1-7.

DOI: 10.1590/2177-6709.25.4.23.e1-7.err.

» The authors report no commercial, proprietary or financial interest in the products or companies described in this article.

Submitted: March 06, 2019 - Revised and accepted: June 12, 2019

Contact address: Luis Ernesto Arriola Guillén

E-mail: luchoarriola@gmail.com 


\section{INTRODUCTION}

It has been reported that individuals with open bite have greater incisor dentoalveolar height, compared with balanced facial pattern subjects. ${ }^{1,2}$ Based on the increased vertical skeletal and dentoalveolar dimensions that open bite individuals present, ${ }^{1,3-7}$ it could be speculated that the root lengths of anterior teeth would be greater in open bite individuals, when compared to those without open bite.

Contrarily, some authors found shorter maxillary central incisor length in open bite patients compared to controls without open bite, ${ }^{8}$ or with deep bite $^{9}$, based on lateral cephalogram evaluation. However, the root length was not directly measured. ${ }^{8,9}$ In addition, only two studies that evaluated dental root length in panoramic radiographs ${ }^{10}$ and root area in $\mathrm{CBCT}^{11}$ concluded that patients with open bite, especially those with a high mandibular plane angle, have shorter dental roots and smaller root areas of the maxillary incisors, when compared to individuals with normal overbite. These studies mention that their findings may be related to the loss of occlusal contact in the anterior teeth. It is important to emphasize that open bite individuals present counterclockwise rotation of the palatal plane and clockwise rotation of the mandibular plane,,$^{5,12-14}$ increasing the lack of contact between maxillary and mandibular incisors. ${ }^{10}$ However, a clear relationship between open bite and the presence of shorter or longer roots is not yet established, since studies that evaluate, specifically, the root length of individuals with open bite have been rarely reported. Thus, these results should be evaluated in other samples for better consistency. ${ }^{15}$

Therefore, the purpose of this study was to compare the root length of maxillary and mandibular incisors between individuals with open bite versus matched individuals with adequate overbite.

\section{MATERIAL AND METHODS}

This comparative and retrospective study was approved by the Ethics and Research Committee of the Universidad Cientifica del Sur, Lima/Peru (\# 00021). The sample involved 48 CBCTs obtained from the files of a radiologic center at the Universidad Cientifica del Sur, of patients who underwent orthodontic-surgical treatment planning. ${ }^{16}$ The CBCTs were divided into two groups: Group 1, consisting of 24 scans of individuals with anterior open bite; and Group 2, consisting of 24 scans of individuals with an adequate overbite (controls). The patients were matched by age, sex, malocclusion classification and skeletal characteristics (ANB and Frankfort mandibular plane-FMA angles).

Sample size was calculated considering an $80 \%$ of test power at a confidence level of $95 \%$, with a mean intergroup difference to be detected of $2 \mathrm{~mm}$ in the root length of maxillary central incisors, with a standard deviation of $1.60 \mathrm{~mm}$, as previously reported..$^{10}$ Although the required sample was 10 individuals per group, 24 subjects per group were included.

The inclusion criteria of the anterior open bite group included individuals with overbite of $0 \mathrm{~mm}$ or less (negative), mandibular plane angle defined by FMA angle $>26^{\circ}$ for both sexes, age range from 20 to 40 years, with all permanent teeth (excluding third molars), with Class I, II or III malocclusions. The control group included individuals with overbite from 1 to $4 \mathrm{~mm}$, and with the same criteria of the open bite group. In both groups, individuals with syndromic craniofacial deformations, maxillofacial surgeries, history of previous orthodontic or orthopedic treatment, incisors with endodontic treatments, impacted canines or tooth loss prior to CBCT were excluded.

CBCT scans of all patients were taken using a tomographic equipment model Picasso Master 3D (Vatech Co., Ltd., Hwaseong, South Korea), set at $8 \mathrm{~mA}, 90 \mathrm{KV}$, isotropic voxel size of $0.3 \mathrm{~mm}$ and exposure time of 20 seconds. Each field of view mode was of $20 \times 19 \mathrm{~cm}$. All variables were measured in the RealScan software (version 2.0, PointNix Co., Ltd., South Korea).

The overbite was measured, using the volumetric reconstruction (VR), as the distance in mm between the incisal edges of the maxillary and mandibular incisors, perpendicular to the occlusal plane. Malocclusion classification was evaluated in the dental casts.

Lateral cephalograms generated from CBCT were used to measure the cephalometric variables. ${ }^{17}$ Skeletal relationship was evaluated with the ANB angle and the facial pattern with the FMA angle.

The root length of each central and lateral maxillary and mandibular incisors was measured in millimeters. To obtain the tomographic cuts, the longitudinal axis of each incisor was located in the axial, 


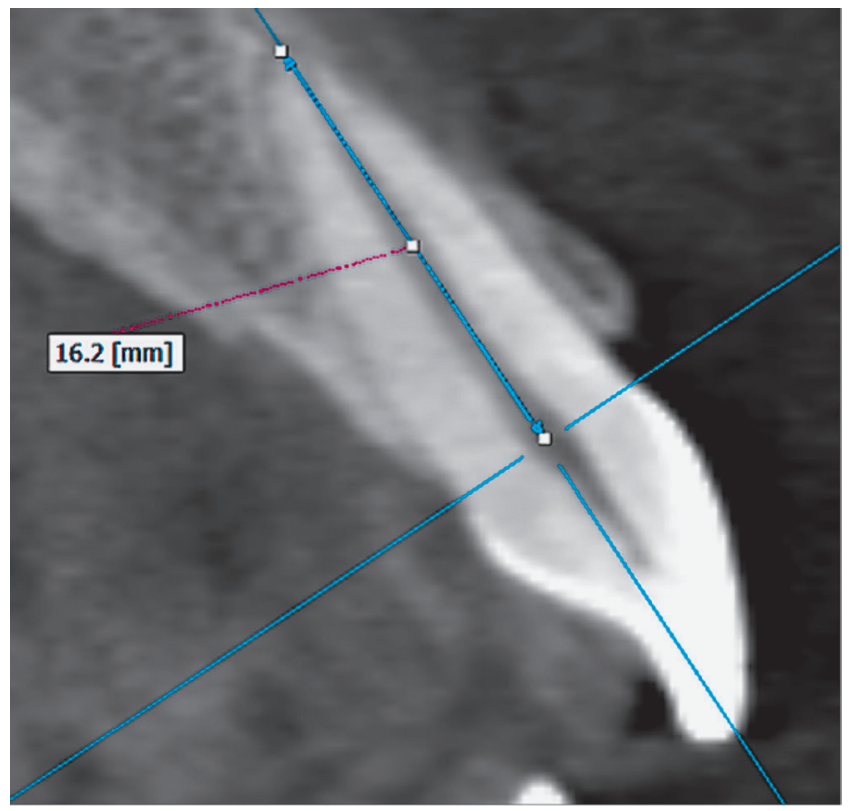

Figure 1 - Root length measurement of maxillary incisor in the sagittal section.

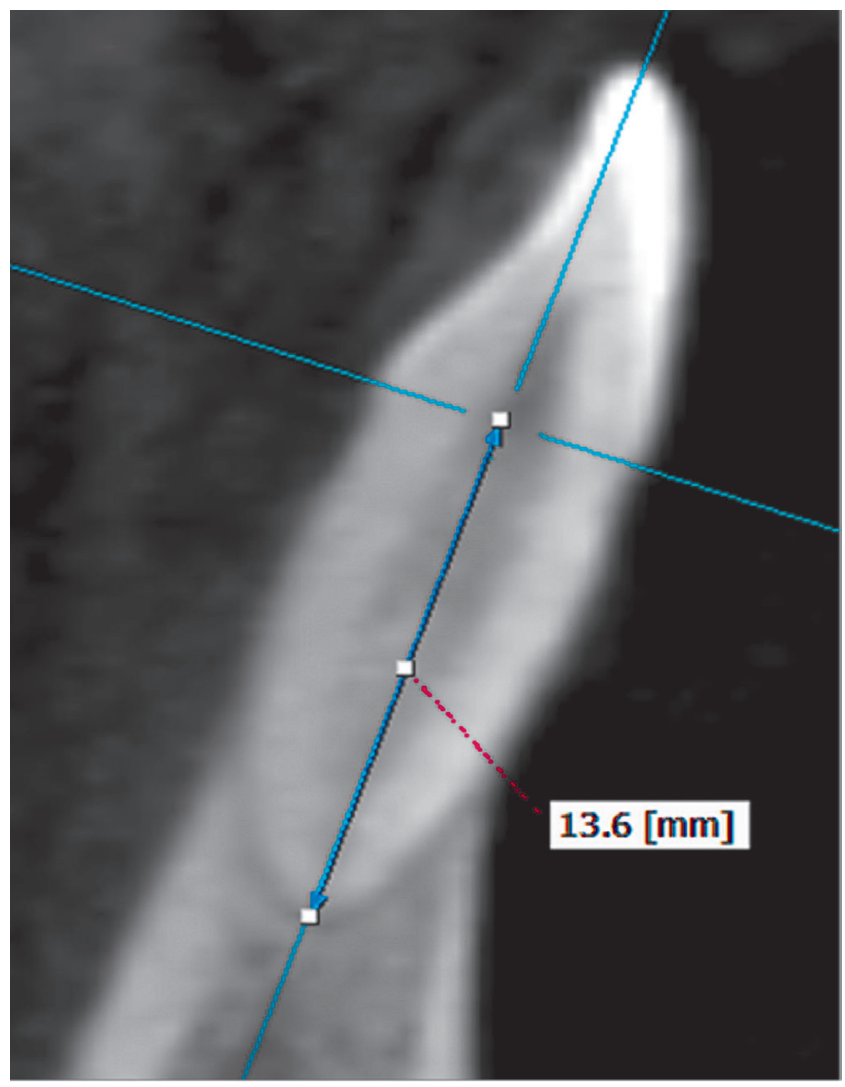

Figure 2 - Root length measurement of mandibular incisor in the sagittal section sagittal and coronal views. Then, in the sagittal section the root length was measured on the same longitudinal axis, from a perpendicular projection of the labial cement-enamel junction up to the vertex of the root apex of each incisor (Figs 1 and 2).

\section{Error study}

All measurements were made twice, at two different times, separated by a one-month interval, by two different examiners. The values obtained were evaluated through the intraclass correlation coefficient (ICC), to determine the intraexaminer and interexaminers concordance. Values greater than 0.85 (CI to 95\%, 0.70-0.98) were obtained. Random errors were calculated according to Dahlberg's formula, ${ }^{18}$ giving values smaller than $1 \mathrm{~mm}$ in all quantitative variables.

\section{Statistical analysis}

All statistical analyses were performed using SPSS software for Windows (version 19.0; IBM, Armonk, NY). Normal distribution was tested and confirmed with the Shapiro-Wilk tests. Intergroup comparisons regarding sex and malocclusion distributions were performed with Chi-square tests. Intergroup comparisons regarding age, overbite, ANB and FMA angles and root lengths were performed with $t$-test. Finally, correlations between overbite and root lengths were evaluated with the Pearson correlation coefficient. The significance level was set at $p<0.05$.

\section{RESULTS}

The groups were comparable regarding sex, malocclusion classification, age, ANB and FMA angles (Tables 1 and 2). The control group presented statistically significant greater overbite than the open bite group (Table 2).

Root lengths ranged from $12.29 \mathrm{~mm}$ to $13.20 \mathrm{~mm}$ for the maxillary incisors, and did not show significant intergroup differences (Table 2).

For the mandibular central incisors, the root lengths ranged from $11.49 \mathrm{~mm}$ to $11.71 \mathrm{~mm}$, and only the root lengths of the open bite mandibular lateral incisors were significantly greater than the normal overbite group.

There were significant inverse correlations between overbite and the root lengths of the mandibular lateral incisors, but with low to moderate strengths (Table 3). 
Table 1 - Distribution of both groups according to sex and malocclusion.

\begin{tabular}{ccccc}
\hline Variable & Values & Control group & Open bite group & Total \\
Sex & Male & 12 & 12 & 24 \\
& Female & 12 & 12 & 24 \\
Angle malocclusion & Class I & 6 & 6 & 12 \\
& Class II & 8 & 8 & 10 \\
& Class III & 10 & 10 & 20 \\
\hline
\end{tabular}

Chi-square test.

Table 2 - Group comparability regarding the initial characteristics and intergroup comparisons of root lengths.

\begin{tabular}{|c|c|c|c|c|c|c|c|c|}
\hline \multirow{2}{*}{ Measurements } & \multicolumn{2}{|c|}{ Control group ( $n=24)$} & \multicolumn{2}{|c|}{ Open bite group ( $n=24$ ) } & \multirow{2}{*}{$\begin{array}{c}\text { Mean } \\
\text { difference }\end{array}$} & \multirow{2}{*}{$\begin{array}{l}\text { Lower Limit } \\
\mathrm{Cl} \text { to } 95 \%\end{array}$} & \multirow{2}{*}{$\begin{array}{l}\text { Upper Limit } \\
\text { Cl to } 95 \%\end{array}$} & \multirow{2}{*}{$p$} \\
\hline & Mean & SD & Mean & SD & & & & \\
\hline \multicolumn{9}{|l|}{ Initial characteristics } \\
\hline Age & 33.80 & 9.07 & 30.89 & 7.40 & 2.91 & -3.24 & 8.57 & 0.343 \\
\hline Overbite & 2.71 & 1.49 & -2.65 & 2.26 & 5.36 & 4.13 & 6.58 & $<0.001^{*}$ \\
\hline \multicolumn{9}{|l|}{ ANB Angle } \\
\hline Class I & 1.31 & 0.21 & 1.23 & 0.77 & 0.08 & -2.35 & 2.50 & 0.907 \\
\hline Class ॥ & 6.20 & 1.22 & 6.42 & 1.49 & -0.22 & -1.34 & 1.45 & 0.857 \\
\hline Class III & -3.37 & 2.02 & -2.35 & 1.85 & -1.01 & -2.84 & 0.80 & 0.257 \\
\hline FMA & 28.10 & 2.43 & 30.15 & 4.34 & -2.05 & -4.35 & 2.50 & 0.079 \\
\hline \multicolumn{9}{|l|}{ Root lengths } \\
\hline Maxillary right central incisor & 12.94 & 1.24 & 12.29 & 1.72 & 0.65 & -0.30 & 1.61 & 0.178 \\
\hline Maxillary left central incisor & 12.81 & 0.98 & 12.50 & 2.26 & 0.31 & -0.81 & 1.42 & 0.583 \\
\hline Maxillary right lateral incisor & 13.06 & 1.31 & 12.96 & 1.79 & 0.10 & -0.91 & 1.10 & 0.849 \\
\hline Maxillary left lateral incisor & 13.12 & 0.80 & 13.20 & 1.65 & -0.08 & -0.90 & 0.75 & 0.846 \\
\hline Mandibular right central incisor & 11.71 & 0.62 & 11.71 & 1.43 & 0.00 & -0.70 & 0.70 & 1.000 \\
\hline Mandibular left central incisor & 11.82 & 0.75 & 11.49 & 1.38 & 0.33 & -0.38 & 1.04 & 0.353 \\
\hline Mandibular right lateral incisor & 11.79 & 0.77 & 12.87 & 1.66 & -1.08 & -1.92 & -0.25 & $0.012^{*}$ \\
\hline Mandibular left lateral incisor & 11.70 & 0.98 & 12.07 & 1.41 & -0.37 & -2.16 & -0.59 & $0.001^{*}$ \\
\hline
\end{tabular}

*Statistically significant at $p<0.05$ (t-test).

Table 3 - Correlation values between the overbite and the root length of maxillary (Mx.) and mandibular (Md.) incisors.

\begin{tabular}{|c|c|c|c|c|c|c|c|c|c|}
\hline $\begin{array}{l}\text { Pearson } \\
\text { correlation }\end{array}$ & & $\begin{array}{l}\text { Mx. right } \\
\text { central } \\
\text { incisor }\end{array}$ & $\begin{array}{l}\text { Mx. left } \\
\text { central } \\
\text { incisor }\end{array}$ & $\begin{array}{l}\text { Mx. right } \\
\text { lateral } \\
\text { incisor }\end{array}$ & $\begin{array}{l}\text { Mx. left } \\
\text { lateral } \\
\text { incisor }\end{array}$ & $\begin{array}{l}\text { Md. right } \\
\text { central } \\
\text { incisor }\end{array}$ & $\begin{array}{l}\text { Md. left } \\
\text { central } \\
\text { incisor }\end{array}$ & $\begin{array}{l}\text { Md. right } \\
\text { lateral } \\
\text { incisor }\end{array}$ & $\begin{array}{l}\text { Md. left } \\
\text { lateral } \\
\text { incisor }\end{array}$ \\
\hline \multirow{2}{*}{ Overbite } & $\mathrm{R}$ & 0.278 & 0.260 & 0.010 & -0.140 & -0.069 & -0.048 & -0.345 & -0.490 \\
\hline & $P$ & 0.176 & 0.105 & 0.949 & 0.390 & 0.671 & 0.771 & $0.029 *$ & $0.001^{*}$ \\
\hline
\end{tabular}

*Statistically significant at $p<0.05$ 


\section{DISCUSSION}

A perfect similarity of the biological and physical characteristics of the individuals in both groups was difficult to achieve due to the great individual variability of the participants. Nevertheless, this is one of the few studies that directly evaluate root lengths in subjects with and without open bite using CBCT scans.

Some authors compared the dentoalveolar height of incisors with respect to the palatal plane, between subjects with and without open bite, finding that individuals with open bite have greater dentoalveolar height of incisors. ${ }^{1,2}$ However, these results only identify that the incisors in open bite subjects have greater dentoalveolar height, but they did not evaluate their root lengths. In this way, Harries and Butler ${ }^{9}$ found, on lateral radiographs, that the length of permanent maxillary central incisors was significantly shorter in adolescents with open bite than matched adolescents with deep bite before orthodontic treatment.

There are a few investigations that have compared the incisor or root lengths between individuals with and without open bite. A first study was carried out by Arntsen et al. ${ }^{8}$ on lateral radiographs and evaluated the entire incisor length, including the crown and the root. They concluded that the length of the upper incisors was smaller in open bite individuals when compared to controls without open bite. Based on these results, it could be thought that if the maxillary incisor length is shorter in open bite individuals, the same may be expected for the root size. However, this is a speculation. In addition, lateral radiographs have the disadvantage of presenting image superimposition of both central incisors, thus the length evaluation of any incisor requires a very good calibration.

Subsequently, Uehara et al. $^{10}$ through panoramic radiographs, compared the root-crown ratio and root length between individuals with open bite and controls with normal overbite. They found that open bite individuals had smaller crown-root ratio and root length from the incisors to premolars in maxillary and mandibular teeth, when compared to individuals with normal overbite. They attributed this characteristic to the loss of occlusal contact, arguing that in the lack of occlusal contact or hypofunction, there could be some atrophic changes in the periodontal ligament that could influence root length. They stated the limitations of using panoramic radiographs and suggested further research using CBCT.
A recent study using CBCT reported that root surface areas of maxillary incisors are smaller in open bite individuals, when compared to controls without open bite. ${ }^{11}$ They attributed their results to the occlusal hypofunction mentioned above, and speculated that some abnormal pressure from a tongue thrusting habit could cause root resorption of these teeth. Nevertheless, their sample size and age range were smaller than in the present study, and it may have influenced their results. In addition, it should be considered that length and area measurements are different. One might find smaller area in a narrow and longer root or a greater area in a wide and shorter root. Thus, area and length measurements should be independently and carefully assessed.

Contrary to the findings of these studies, it could be thought that if open bite patients present greater vertical dimensions and dentoalveolar heights than subjects with normal overbite, ${ }^{1,3-6}$ the presence of similar or even greater dental tooth size and consequently greater root length could be expected. However, the results of this study showed no significant difference in root length of maxillary incisors between subjects with and without open bite (Table 2). This may be explained because the groups did not show significant difference regarding the vertical skeletal pattern. In groups with significant vertical skeletal differences, this scenario may change, and this should be evaluated in future research.

Since no significant differences were found for the maxillary incisors, the same results would be expected for the mandibular incisors. However, significant differences were found in the lateral incisors, showing that individuals with open bite have greater root length, ranging from $0.37 \mathrm{~mm}$ to $1 \mathrm{~mm}$, approximately, when compared to the control individuals (Table 2). In addition, significant inverse correlations were found between root length of mandibular lateral incisors and overbite; however, they presented low to moderate strength, which is not clinically relevant (Table 3). Although these results are in accordance with the speculations of greater root length in open bite subjects, these differences lack clinical relevance. Again, further studies comparing extreme vertical malocclusions should be performed to confirm these results.

If incisors with short roots are a typical characteristic of individuals with open bite malocclusion, this should be a common finding in the different published studies involving different samples. However, the lack 
of articles that evaluate this association, i.e., lack of consistency (previous articles supporting this relationship), ${ }^{15}$ beyond those mentioned above, make it difficult to justify this conclusion. Therefore, future studies are necessary to clarify this causality relationship. Furthermore, for the existence of a cause-effect relationship between two variables (i.e., the existence of short roots and the presence of an open bite), certain specific characteristics should be necessary to eliminate any type of coincidence. Thus, the concept of temporality (firstly, existence of the independent variable; and secondly, presence of the outcome variable) is essential, but this could only be evaluated and demonstrated through follow-up studies ensuring the absence of the outcome variable at the beginning of the study. Plausibility (biological explanation of this relationship) is another concept that should be clear to ensure this relationship, that is defined as the biological explanation why individuals with an open bite could have short roots. Likewise, the strength of association, the biological gradient and coherence are other factors that a causal relationship should also fulfill. ${ }^{15}$ The present study, by its own design, did not seek to evaluate a true causality relationship, but sought to determine whether root length presents significant differences between comparable individuals with and without open bite, information that could be applied in clinical practice.

Consequently, associating the present results with the controversy about greater root resorption after orthodontic treatment in open bite patients, ${ }^{19-21}$ the orthodontist could understand that treatment planning in individuals with and without open bite should have similar considerations regarding the initial condition of root length. In both cases, factors that could cause moderate root resorption of incisors should be similarly avoided.

\section{CONCLUSIONS}

Root length of maxillary incisors and mandibular central incisors is similar in individuals with or without open bite, but root lengths of mandibular lateral incisors in the open bite group were significantly greater than in the normal overbite group.

\section{Authors contribution (ORCID ${ }^{(1)}$ )}

Luis E. A. Guillén (LEAG): 0000-0003-0010-5948 Ivy S. V. Montoya (ISVM): 0000-0002-6953-4591 룽

Yalil A. R. Cárdenas (YARC): 0000-0002-3107-3013 Gustavo A. R. M. (GARM): 0000-0002-9954-1047 ${ }^{\text {(B) }}$ Aron Aliaga-Del C. (AADC): 0000-0003-3963-1742 Guilherme Janson (GJ): 0000-0001-5969-5175 iㅣ

Conception or design of the study: LEAG, ISVM. Data acquisition, analysis or interpretation: LEAG, ISVM, YARC, GARM, AADC, GJ. Writing the article: LEAG, ISVM, YARC, GARM, AADC, GJ. Critical revision of the article: LEAG, ISVM, YARC, GARM, AADC, GJ. Final approval of the article: LEAG, ISVM, YARC, GARM, AADC, GJ. Obtained funding: LEAG, ISVM. Overall responsibility: LEAG, ISVM, AADC. 


\section{REFERENCES}

1. Arriola-Guillén LE, Flores-Mir C. Anterior maxillary dentoalveolar and skeletal cephalometric factors involved in upper incisor crown exposure in subjects with Class II and III skeletal open bite. Angle Orthod 2015;85:72-79.

2. Kucera J, Marek I, Tycova H, Baccetti T. Molar height and dentoalveolar compensation in adult subjects with skeletal open bite. Angle Orthod. 2011;81:564-9

3. Subtelny JD, Sakuda M. Open-bite: diagnosis and treatment. Am J Orthod. 1964:50:337-358

4. Arriola-Guillén LE, Flores-Mir C. Molar heights and incisor inclinations in adults with Class II and Class III skeletal open-bite malocclusions. Am J Orthod Dentofacial Orthop. 2014;145:325-332.

5. Janson G, Valarelli F. Open-bite malocclusion, treatment and stability. Iowa, USA: Wiley Blackwell; 2014

6. Ngan P. Fields HW. Open bite: a review of etiology and management Pediatr Dent. 1997:19:91-8

7. Beckmann SH, Kuitert RB, Prahl-Andersen B, Segner D, The RP, Tuinzing DB. Alveolar and skeletal dimensions associated with overbite. Am J Orthod Dentofacial Orthop. 1998:113:443-52.

8. Arntsen T, Kjaer I, Sonnesen L. Lengths of the maxillary central incisor, the nasal bone, and the anterior cranial base in different skeletal malocclusions. Acta Odontol Scand. 2009;67:265-270.

9. Harris EF, Butler ML. Patterns of incisor root resorption before and after orthodontic correction in cases with anterior open bites. Am J Orthod Dentofacial Orthop. 1992;101:112-9.

10. Uehara S, Maeda A, Tomonari H, Miyawaki S. Relationships between the root-crown ratio and the loss of occlusal contact and high mandibular plane angle in patients with open bite. Angle Orthod. 2013:83:36-42.

11. Suteerapongpun $P$, Sirabanchongkran $S$, Wattanachai $T$, Sriwilas $P$, Jotikasthira D. Root surface areas of maxillary permanent teeth in anterior normal overbite and anterior open bite assessed using conebeam computed tomography. Imaging Sci Dent. 2017;47:241-246.

12. Deguchi T, Kurosaka H, Oikawa H, Kuroda S, Takahashi I, Yamashiro T, et al. Comparison of orthodontic treatment outcomes in adults with skeletal open bite between conventional edgewise treatment and implant-anchored orthodontics. Am J Orthod Dentofacial Orthop. 2011;139:560-68
13. Cruz-Escalante MA, Aliaga-Del Castillo A Soldevilla L, Janson G, Yatabe M, Zuazola RV. Extreme skeletal open bite correction with vertical elastics. Angle Orthod. 2017:87:911-23.

14. Chang YI, Moon SC. Cephalometric evaluation of the anterior open bite treatment. Am J Orthod Dentofacial Orthop. 1999:115:29-38.

15. Fedak KM, Bernal A, Capshaw ZA, Gross S. Applying the Bradford Hill criteria in the 21st century: how data integration has changed causal inference in molecular epidemiology. Emerg Themes Epidemiol. 2015:12:14.

16. American Academy of Oral and Maxillofacial Radiology. Clinical recommendations regarding use of cone beam computed tomography in orthodontics. [corrected]. Position statement by the American Academy of Oral and Maxillofacial Radiology [published correction appears in Oral Surg Oral Med Oral Pathol Oral Radiol. 2013 Nov:116(5):661]. Oral Surg Oral Med Oral Pathol Oral Radiol. 2013:116(2):238-257.

17. Hariharan A, Diwakar NR, Jayanthi K, Hema HM, Deepukrishna S Ghaste SR. The reliability of cephalometric measurements in oral and maxillofacial imaging: cone beam computed tomography versus twodimensional digital cephalograms. Indian J Dent Res. 2016:27:370-377.

18. Dahlberg G. Statistical methods for medical and biological students. New York: Interscience Publications; 1940.

19. Freitas MR, Beltrao RT, Janson G, Henriques JF, Chiqueto K. Evaluation of root resorption after open bite treatment with and without extractions. Am J Orthod Dentofacial Orthop. 2007:132:143 e115-122.

20. Elhaddaoui R, Benyahia H, Azeroual MF, Zaoui F, Razine R, Bahije L. Resorption of maxillary incisors after orthodontic treatment--clinical study of risk factors. Int Orthod. 2016:14:48-64.

21. Motokawa M, Terao A, Kaku M, Kawata T, Gonzales C, Darendeliler MA, et al. Open bite as a risk factor for orthodontic root resorption. Eur J Orthod. 2013:35:790-795

\section{ERRATUM}

The original article "Incisor root length in individuals with and without anterior open bite: a comparative CBCT study", with DOI: 10.1590/2177-6709.25.4.23.e1-7.onl, published in Dental Press J Orthod, vol. 25, no. 4, July/Aug. 2020, Epub Sep 21, 2020, had in authorship the following authors: Luis Ernesto Arriola-Guillén, Ivy Samantha Valera-Montoya, Yalil Augusto Rodríguez-Cárdenas, Gustavo Armando Ruíz-Mora, Aron Aliaga-Del Castillo and Guillerme Janson

\section{Now the article should have the following row of authors and "How to cite this article":}

Luis Ernesto Arriola-Guillén, Ivy Samantha Valera-Montoya, Yalil Augusto Rodríguez-Cárdenas, Gustavo Armando Ruíz-Mora, Aron Aliaga-Del Castillo and Guilherme Janson

Arriola-Guillén LE, Valera-Montoya IS, Rodríguez-Cárdenas YA, Ruíz-Mora GA, Aliaga-Del Castillo A, Janson G. Incisor root length in individuals with and without anterior open bite: a comparative CBCT study. Dental Press J Orthod. 2020 JulAug;25(4):23e1-7. doi: 10.1590/2177-6709.25.4.23.e1-7.err. PMID: 32965383.

\section{DOI: https://doi.org/10.1590/2177-6709.25.4.23.e1-7.err}

